\title{
Killing animals: sociology, species relations and institutionalised violence
}

\begin{abstract}
Influential voices have argued for a sociology which acknowledges the way we are co-constituted with a range of non-human species as part of the condition of life on this planet. Despite this, sociology has generally retained a conception of the social that is centred on the human. This paper argues for the inclusion of non-human animals in sociological agendas, focusing on the emerging field of the sociology of violence. It examines the institutions and processes through which non-human animals are subjected to different forms of violence, most notably, mass killing. The practice of killing animals is routine, normative, institutionalised and globalised. The scale of killing is historically unprecedented and the numbers killed are enormous. The paper argues that this killing of non-humans raises questions around inequalities and intersectionality, human relations with other species, the embedding of violence in everyday practices and links between micro and macro analyses. These are questions with which the new sociology of violence might engage.
\end{abstract}

\section{Keywords}

Human-animal relations, institutionalised violence, farmed animals, companion animals 


\section{Introduction}

In her essay, 'Being Prey', Val Plumwood (1996) reflects on her experience of being attacked by a crocodile. While the crocodile attempts to kill her, Plumwood feels outraged - she is human and should not be food. She suggests that it is a mark of our status as beyond and above 'the animal' that we cannot position ourselves as prey. On the other hand, we do not usually think of ourselves as predatory animals, despite being highly effective in this regard. The most common relationship we have with domesticated non-human animals is that we eat them, and this requires the routine killing of enormous numbers.

The farming of animals is the most significant social formation of human-animal relations in terms of scale and reach. Globally, ninety nine per cent of all domesticates are commodities in animal agriculture (Williams and de Mello, 2007: 14). The statistics are of staggering proportions. At least 55 billion land-based nonhuman animals are killed in the farming industry per year (Mitchell, 2011). Figures are projected to increase substantially with an extra 360 million cattle and buffaloes, 560 million extra sheep and goats, and 190 million extra pigs needed by 2030 to match growing consumer demand (Food and Agriculture Organization, 2002). Even domesticate 'companions' such as dogs and cats, are systematically killed. Living outside human households makes such animals vulnerable - feral animals taken to shelters in Britain and the United States are usually euthanized (Palmer, 2006: 171). The numbers are clearly 'small' compared to the billions killed for food, but are nevertheless remarkable. The American Society for the Prevention of Cruelty to Animals figures for 2012 estimate that between three and four million 'stray dogs and cats' were killed by shelters (ASPCA, 2013). These levels of routine and normative killing of those animals we refer to as 'livestock' and 'pets' is not, however, an issue that has concerned sociologists of violence. 
In sociology, violence has been understood as both individual and collective but as unmistakably a social phenomenon, socially organized and socially institutionalized (Stanko, 2001; Ray, 2011). There are specific arenas where violence is seen to occur - in sport, in war, in the home (domestic violence), and in association with criminal behavior. In some cases, this violence is linked to widespread forms of inequality and social exclusion (Toombs, 2007). Forms of violence have been understood to reflect multiple forms of domination - for example, feminist work has drawn our attention to the intersected qualities of racialised, gendered violence in situations of armed conflict (Cockburn, 2007). However, species is not factored into such analyses despite that non-human animals are embedded in the social institutions and processes of intra-human violence.

In thinking about the killing of domestic animals in more developed countries, this paper attempts a posthumanist intervention in the agenda of the emerging sociology of violence. Sociological animal studies are increasingly demonstrating the more-than-human character of the social world. As a new area of sociological enquiry, violence studies might acknowledge that human violence implicates other species in a variety of social forms. Animals are caught up in the landscape of intra-human violence, as combatant tools in the conduct of war or non-combatant victims, for example. The main focus of the paper however is on routinized and naturalized animal killing and the processes through which certain species of non-human animals are subjected to different forms of human violence. This 'non-criminal putting to death' (Derrida, 1991) of non-humans raises sociological questions around intersectionality, human relations with other species and the embedding of violence in everyday practices and across national and global networks. The paper builds its argument for the inclusion of non-human animals in the 
emerging agenda of the sociology of violence by considering, in turn: species relations as a sociological subject; the sociology of violence; and some of the institutions and practices of animal killing. Finally the paper indicates how we might think about such violences sociologically.

\section{Animal-human relations as a sociological subject}

In the footsteps of foundational figures such as Simmel and Durkheim, sociology has understood 'society' as something that emerges 'through the symbolically constituted and linguistically mediated encounters and interactions through which meanings and representations are communicated from one mind to another in the course of human association' (Scott, 2010: 1617). Whilst sociology has broadened its subjects, objects and processes of study, it has held fairly fast to this conception of the social as centred on the human. Even more critical sociologies are resistant to the study of non-human animals, shaped by the belief that studying non-human animals lessens or undermines the notion of oppression (Alger, 2003; Arluke, 2004). There are two difficulties here: first, that human-exclusivity reveals a partial picture of social lives; second, that this exclusivity is such that even critical sociologies have shown reticence in taking the notion of the oppression of other animals on board.

There are various responses to these predicaments. The least controversial for the disciplinary mainstream is a position that considers human relations with non-human animals to be revealing about human beings themselves. Tester (1992: 68-88), for example, draws on the work of Elias in suggesting that the development of anti-cruelty legislation was part of the 'civilizing process' to discipline the working class, rather than a move to extend humanitarian goals to other species or prevent violence against non-human creatures. Whilst such an approach sees non-human animals as sociologically 
relevant, it does not recognise the co-constitutive role of non-human species in social life. An alternative to additive approaches is a critical sociology in which species relations are problematized. An example here would be the work of Nibert (2002: 7), who explicitly uses the concept of oppression in relation to the historical development of human relations with non-human animals. Speciesism is 'an ideology, a belief system that legitimates and inspires prejudice and discrimination' (2007: 17) is discursively and materially constituted in cultural processes and institutional arenas through which animals are exploited and oppressed - zoos, the 'use' of animals in research, hunting, farming and slaughter. As Nibert suggests, human relations with other species are constituted by and through social institutions and processes. These can be seen as sets of relations of power and domination, which are consequential of normative practice and as I have previously suggested, might be understood, to form a social system of human domination, one element of which is 'violence' (Author, 2011a). The social and ecological effects of species as system of relational power are co-constituted with other kinds of complex forms of domination and assume specific spatialized and historical formations. This understanding of species as relational and institutionalized helps us to think sociologically about violence and domesticated animals.

\section{The new sociology of violence}

Whilst the turn towards violence is a recent phenomenon, it is not that sociology has been uninterested in this subject. As Walby (2013) notes, the study of violence has been an important element of sociological theorizing of forms of governance and large scale social change, as well as the study of everyday life, and its presence is felt clearly in the work of classical sociologists. This is particularly so in the case of the macro theorizing of those such as Weber 
(1978) and Arendt (1970) and in more contemporary social theory (Giddens, 1996; Tilly, 2003). McKie (2006: 1.3) suggests that more critical sociological approaches to violence might adopt a broader definition covering various oppressive behaviours and outcomes, and include symbolic and structural violence. In defining the scope of the field, Walby contends that 'war, terrorism, securitization, ethnic cleansing, domestic violence, violent crime and hate crime' are to be included (2013: 95).

Whilst these categories of violence may suggest only human protagonists and victims, institutions and practices, this is not so. Non-human animals are implicated in the violent practices of human households, and non-human animals are themselves victims in domestic violence situations and used as weapons against human victims of abuse (Adams, 1996; Ascione, 1997). Nonhuman animals are also implicated in the practices of warfare and securitisation as labour, by being weaponized or serving to enhance human capabilities (Author and Author, 2014). Whilst the uses of horses, camels and dogs in warfare is an ancient practice, newer members of the military industrial complex include sea lions, pigeons, bees and dolphins (Hediger, 2012).

Walby's definition of violence is more restricted in scope than that of McKie, and emphasises the physical quality of violent practices. Walby would allow that violence is linked to sets of social relations and formations of social power but wants violence considered as 'a distinctive practice that is not reducible to other forms of power or practice' (2013: 104). In analysing the distinct qualities of violence sociologically, I consider a restricted definition to be helpful but am less certain than Walby that it is straightforward to separate the distinct qualities of forms of violence from its use as a tool of power or its embedding in sets of social relations. Rather, the institutions and practices of 
embodied violence are necessarily to be understood and theorised in relation to wider questions of social power.

Walby argues that there are two major forms of sociological study in the field of violence: 'interpersonal violence', often understood in terms of violent crime, and 'inter-state war', including so-called 'new' wars of terrorism and genocide, and the increased prominence of guerrilla tactics. This broadly private/public distinction is explicitly linked to gendered divisions between macro and micro sociologies:

The study of violence in intimate relationships and families tends to be located in the arena of gender and women's studies with attendant conferences, journals and networks. By contrast, sociological work on war and civil unrest resides in what might be termed mainstream work with theorising on states, institutions and international relations, again within specific networks and outlets for work. While the former is notable for feminist and pro feminist perspectives, the latter draws upon classic and contemporary work that tends to consider the inter-play of social structures, social cohesion and institutions at a macro level (McKie, 2006: 1.2)

This patterning is an emerging difficulty in developing the field of violence studies in sociology. Feminist scholarship in international relations has important lessons for us here. Investigations into the gendering of militarism and militarization links domestic contexts to local institutions, priorities of nation states and practices of interstate conflict. For example, the well-known work of those such as Cynthia Enloe $(2000,2007)$ and J. Ann Tickner (2001) has illuminated male dominance of hierarchies in military institutions, their hypermasculinized cultures and the gendered notion of protection. There has been much discussion of rape as a weapon of war, of the predicament of 'survival sex' for vulnerable women and girls, and of sexual misconduct and domestic abuse (Cohn, 2013; Leatherman, 2011). McKie and Larry Ray (2000) have argued 
that violence in everyday life is not seen as remarkable sociologically, unlike the violence associated with interstate conflict. Feminist international relations scholarship however has strongly argued and effectively demonstrated that violence is embedded in everyday practices, institutionalised and normative across various scales - local, national and transnational.

The following sections of this paper use a restricted definition of violence as behaviour and practices involving physical force or power that adversely affect, hurt, damage and in particular, kill. I focus on the everyday forms of physical violence against domesticated non-human animals, particularly mass killing. In covering this terrain, I hope to show some of the ways in which everyday violence is multi-scalar and that micro and macro levels of social violence are interconnected.

\section{Animals and human violence}

There is a range of ways in which non-human animals are killed, reflected in the terms used to describe animal killing:

...gassed, electrocuted, exterminated, hunted, butchered, vivisected, shot, trapped, snared, run over, lethally injected, culled, sacrificed, slaughtered, executed, euthanized, destroyed, put down, put to sleep, and even, perhaps, murdered. (Animal Studies Group, 2006: 3)

The use of such terminology extends some of the language of violence (such as murder or rape) to non-humans and breaks with legally derived definitions based on harm or injury to persons. This accompanies both theoretical and practical political challenges to the humancentrism of the notion of the 'person' who might be the subject of harm. While the humancentrist equation of 'personhood' with the human has been challenged on biological and philosophical grounds (Bekoff, 2002; Francione, 2008), some countries have 
broadened the legal boundaries of personhood (to include, for example, nonhuman great apes in Spain since 2008, and dolphins and whales in India since 2013). There is not space here to engage with the demands that the range of species difference raises for an extended notion of violence, rather to suggest that a humancentrist agenda excludes the ways non-human beings are caught up in violent social practices which are wide scale, systemic and normalized. In addition, for some species, such as those raised as domesticates, violence can be seen to operate in similar ways to violences affecting humans; for example, they are subjected to the intentional use of both power and physical force to injure, kill or physically harm them (in line with World Health Organization (WHO) definition, 2002). These forms of violence can be individualised or collective in form, and have their own specific repertoire of cultural and material formations and practices.

Feminist work on gender-based violence in situations of armed conflict has painted a frightening picture of what happens to human beings in circumstances where routine violence and killing becomes a 'runaway norm' unravelling the legal and cultural taboos which police intra-human violence (Leatherman, 2011: 9). In these situations, human beings find, disturbingly, that 'we are all, after all, potentially animals before the law' (Wolfe, 2013: 105). The animalization of humans (as 'vermin' for example, in the well-known cases of Nazi Germany where Jewish people were referred to as rats and lice, or the Rwandan genocide in which Tutsis became cockroaches) has been an effective means of suspending prohibition on violence against humans and legitimating mass killing. For non-humans however, different moral status enables mass killing to be routine rather than exceptional, and to be normalised. For Wolfe, this is because animals are 'before the law'. That is, that animals are subjected to 'originary violence' in the sense that the human/animal distinction is antecedent 
to the law and codified by it (Wolfe, 2013: 9). This invites parallels with the treatment of others seen as outside the frame of law in certain periods and cultures (women, for example, Pateman, 1988). Wolfe suggests that the human/animal distinction is continually reinforced by the 'violence of sacrifice', that is, that animals are sacrificeable whereas humans, most usually, are not. Here he draws on Derrida's notion that 'beasts' (non-human animals and animalized humans) fall below the law (Derrida, 2009: 20-21) and thus might be subjected to a routine, large scale 'non-criminal putting to death' (Derrida, 1991). This routine killing enables the law to disavow its own contingency by permitting the breeding, exploitation and killing of some animals for food, whilst redefining the frame of who is 'in' and who is 'out' by granting others, such as great apes, some basic human rights (Wolfe, 2013: 11).

The killing I have been particularly interested in is that involving domesticate animals. In his sociology of domestication, or rather 'domesecration', Nibert understands the processes of domestication to be violent in and of themselves (2013: 24-30). Whilst Nibert's intersectionalised approach has much to offer the analysis of the oppressive relations between human and other animals, there is little room for considering differences in the forms domestication takes, the levels of violence these operationalise and how these map on to specific kinds of relations between ourselves and certain species. Elsewhere, I have argued that there are different degrees to which humans might be seen to dominate other species, and that in different sites of human-animal relation, such as farming or companionship, these might be evidenced (Author, 2011a). When it comes to the violence implied in each of these sites of relations there are also both similarities and differences to be found. For example, some small scale farmers might have empathetic and close relations with the animals they raise for food (Wilkie, 2010), and these are 
similar in some ways to relations with animals kept in the some homes (Author, 2011b). Alternatively, some pet owners act towards 'pet' animals with negligence, and seek to discard animals no longer attractive or useful. Despite this, there is a distinction in the language of killing that does refer to differences in practice: euthanasia, as opposed to slaughter (Swabe, 2009: 252). In both cases, animals are seen to meet a 'non-criminal putting to death', and there are overlaps in the forms of killing. First, both are cold (objective and dispassionate) rather than 'hot' (such as the impassioned killing of hunting, Marvin, 2006: 16). Marvin observes that we have two models of 'cold' killing: industrial and medical. In the medical mode, companion animals may be given a lethal dose of barbiturates by a veterinarian when their owner decides it is in the best interests of a suffering animal, or, and unfortunately often, when an animal is no longer wanted or judged capable of living the life of a 'pet'.

Certainly medical killing differs significantly in motivation. There are veterinarians and owners of companion animals working hard to minimize pain, maximize quality of life and to secure as 'good' as death as is possible (see Pierce, 2012). Despite this, the numbers of animals abandoned and given up to shelters to be rehomed, or often, destroyed, is a harsh reminder of the ways in which even those animals receiving higher levels of legal protection might still in huge numbers meet a premature 'non-criminal putting to death'. In the industrial mode, billions of animals are killed for food. There are developments which suggest that animal welfare is increasingly embedded in public policy for agricultural animals (Buller, 2013) including at the point of slaughter (Grandin, 2009; Miele, 2013). Yet 'gains' in terms of minimizing animal suffering here are both partial and ambiguous (Miele and Lever, 2013); perhaps more so than in the case of companion animals and perhaps unsurprisingly, given the different functions these animals fulfil in serving human interests. 
These two sites represent case studies of the killing of animals differentiated in terms of scale and reach. The first provides an illustration of national context and the killing of species that, in countries such as Britain and the US, are presumed to be 'close' to humans and often have attachments to humans as individuals. The nature of this killing is in some cases, more ambiguous than that involving agricultural species and may be undertaken in the 'best interests' of an animal irremediably ill and in pain. The second case illustrates the global networks of animal breeding, growing and killing for species that are understood overwhelmingly as 'livestock'.

\section{Methods and data}

The purpose of this paper is to disturb a humancentric tendency in the emerging agenda of sociological violence studies. In doing so, it presents a range of illustrative examples, some of which draw on elements of established research projects. New material and older data are brought together here specifically to exemplify the systemic and structural qualities of violence apparent in human relations with domesticate animals at both micro and macro levels. Empirical research draws upon documentary material from various UK sources such as government reports (from quangos such as the Farm Animal Welfare Council (FAWC) or the Department for Farming and Rural Affairs (Defra), or from animal welfare pressure groups such as Compassion in World Farming (CIWF)). Additional documentary material takes the form of news media pieces; websites and television programmes (such as the BBC's 'Kill it, cook it, eat it' series). Drawing on documentary sources which are relatively supportive of, for example, the industries of animal agriculture, such as Defra and those which are relatively critical, such as CIWF, enables a more balanced account. 
There are references also to ethnographic material from interviews and observation. Some material is drawn from an ethnographic diary of encounters with dogs and their people in part of London's Lea Valley Park. Detailed field notes kept in the form of diary entries were taken for a calendar year across 2009-10. In addition, material is drawn from semi-structured interviews with dog 'owners', investigating their relationships and lives with canine companions. Thirty seven interviews were undertaken in 2010 and 2011 with people walking dogs in Walthamstow and Hackney marshes which form part of the Park. The study focused on the positive relationships between people and companion dogs and all the dog 'owners' in the study were 'responsible' in terms of regularly walking with dogs and demonstrating concern and care about them. This project did not intend at the outset to research issues of maltreatment or of violence, yet the data was surprisingly revealing of the 'dark side' of dog ownership with over half of the participants in the study living with dogs they had obtained via rescue organisations. As a result, a theme in the data is the vulnerability of dogs as 'pets'. Violence is also a distinctive presence in many dog owners' narratives of their experiences and observations of human-dog relationships.

Other ethnographic material is drawn from earlier observations in slaughterhouses in central London (Smithfield Market in 1994) and in Essex (Romford, between 1994 and 1995). During this time I undertook interviews with local authority inspectors (four members of staff from one inner London and one outer London authority; three members of staff from Essex), slaughterhouse workers (six members of staff in three locations) and meat packing staff (three members of staff in one location in Essex). At the time this study was undertaken, the key focus was not to examine practices of violence specifically, but social relations of species more generally, and particularly in 
terms of intersected relations of difference and inequality. Further developments in sociological animal studies and the re-emergence of violence as a subject of sociological interest has prompted me to return to this data.

The following two sections draws together material from sociological animal studies alongside a number of illustrations from my own data in order to exemplify what sociologists might pay attention to - significant levels of different forms of violence and its patterned qualities. Such violence is a constituent element of human relations with domesticate animals.

\section{$\underline{\text { Killing companions }}$}

In the West, even animals which are relatively privileged are subjected to a range of violent practices. We are able to purchase rodents, snakes, spiders, horses, cats and dogs very easily and abandon them with few difficulties. For Bob Torres, the legal ownership of companion animals makes them incredibly vulnerable and they might be euthanized at the whim of the owner (2007: 156-57). The large scale commercial breeding of companion animals relies on sophisticated marketing to boost demand, maximizes profits through highly intensive and often cruel methods, and oversupplies animals for the pet trade to the extent that, in the US for example 'animal shelters are forced to destroy millions of unwanted pets each year' (Williams and de Mello 2007: 238-253). In addition, the treatment of some breeding animals mirrors the treatment of intensively farmed animals such as pigs, and is similarly dependent on gendered manipulation of fertility and sexuality and on occasion, sexualized abuse (Dunnayer, 1995: 14); whilst notions of breed purity and pedigree breeding narratives are constituted through strongly classed and racialised discourse (McHugh, 2004: 91-95). 
In addition, human inequalities undermine the security of companion animals who may be subject, for example, to domestic violence. Threats to harm or kill family pets are used as threats against women and children (Adams, 1995). Pets themselves become victims of battering and may be mutilated, executed or otherwise harmed (Acione, 1997). This often impacts on both battered women and animal companions that survive abuse, both psychologically and practically (Flynn, 2000). Estimates by animal welfare charities in Britain and the US, indicate that numbers of companion animals abandoned, mistreated (in organised fights, by drowning, stabbing, burning or by neglect) is statistically significant, and seems to be on the increase in times of economic hardship (Wedderburn, 2011).

My ethnographic work on canine-human relations revealed high levels of anxiety amongst dog owners about a popular culture of machismo in which bull-breed dogs were implicated as weapons or trophies. Tales of such dogs and human misanthropy are often interwoven. When the River Lea which runs through the park, was dredged, hundreds of bodies of Staffordshire terrier ('staff') and staff-cross puppies and dogs were found. One potential such case managed to find its way into my field notes:

a white staff puppy, very small...they have it by 'mistake'. A client she works with came across some guys about to throw it in the river and drown it. It was the runt of the litter and they couldn't get the money they wanted for it. (field notes, July 2009)

Another case prompted much discussion amongst dog walkers in 2011. The police were called because of a trail of blood found by an early morning dogwalker. The dying dog had dragged itself under bushes having been stabbed with a knife over twenty times: 
It was a gang-dog, a kid's dog. That's what I heard. They thought there was a body in the bushes, and it was a body, but it was a dog body. Would the police have bothered if it was a dog? They came because they thought it was a kid. (interview, Lea Valley Park, October 2011)

Well, they're trophy-dogs and this is a trophy-kill. Well, I would say that poor bloody dog was murdered. It was murdered. They stabbed it to death for revenge. (interview, Lea Valley Park, December 2011)

The levels of systematic cruelty against dogs, and negative attitudes towards dogs were of concern to most of my interviewees. Many had adopted dogs from rescue and rehoming centres and programmes of different kinds, and tales of various forms of human misanthropy are embedded in the stories of rescue dog lives from incarceration, starvation and routine beating to wounding with knifes and cigarettes.

For some, a significant concern was the difficulties rehoming abandoned dogs of bull-breeds with which animal welfare organisation have been overwhelmed. While organizations such as the RSPCA have campaigned to change the reputation of such dogs, the Dangerous Dogs Act (DDA) of 1991 in the UK legitimated mass killing of certain 'types'. This legislation specified unacceptable 'dog behaviour' and covers all breeds of dog. However, it is also a form of 'breed specific' legislation. The Act introduced a list of banned dogs American Pit Bull terriers and three kinds of mixed mastiff breeds. If judged by a magistrate to have 'sufficient breed characteristics', dogs of these types must be destroyed (Defra, 2009: 11). The legislation was hastily passed at the height of media focus on 'dangerous dogs' which centred on a number of attacks by American Pit Bull terriers. Whilst the legislation has done nothing to reverse an apparent trend in attacks on humans by dogs, it has resulted in the seizure, incarceration and killing of large numbers of dogs, 1,152 were seized by the London Metropolitan police in 2009 alone (Barkham and Murphy, 2012). Police 
have simply to 'believe' that a dog may be of a banned type in order to seize and incarcerate (Defra, 2009). Since the Act became law, animal welfare groups have observed a rise in the breeding of American Pit Bull mixed breed dogs. These dogs are now often rejected by rehoming centres or taken in and destroyed. Battersea Dogs and Cats Home in London killed 2,815 of such dogs in 2010. In many cases, their killing is compelled despite behavioural assessment by animal welfare organizations:

Some dogs brought into our centres, as part of cruelty investigations, are later identified by the police as a prohibited type. Despite many of these dogs being friendly, well socialized and perfect candidates for rehoming to responsible owners, the law doesn't allow them to be rehomed. (RSPCA, 2014)

'Specific breed' legislation allows no consideration of individual cases or the context of human relations in which a dog finds itself. It has been called 'racist' in that physical features of appearance make individual dogs a target of the legislation (www.ddawatch.co.uk). The ways in which individual dogs are physically appraised certainly raises the question of the racialization of species, as does the legal presumption that these dogs are prima facie legally 'dangerous' or 'vicious' by genetic disposition.

Thus in the case of domesticates kept as companions, there is a range of violences, some legitimate (killing by veterinarians and in the case of 'dangerous' dogs, by the police) others illegitimate (pets killed, beaten or terrorised) and often related to other forms of violence (domestic violence, gang related violence). Whilst the killing of animals by lethal injection may indeed be in the interests of animals who are dying, terminally ill and/or in severe pain, 
large numbers are killed routinely in the pet industry, by neglect and by veterinarians working with companion dogs and with dog rescue. The inability of 'owners' and of animal welfare organisations to protect 'types' of dog from culling under the DDA is illustrative of the vulnerability of animals 'before the $l^{\prime} w^{\prime}$. The number of animals killed here pales into statistical insignificance however, when compared to the mass killing of animals for food.

\section{Killing for food}

The development of the global model of industrialised meat production was established through species genocide. The cattelisation of the North American prairies is an important case in point with the white settler state sponsoring the mass extermination of the buffalo and their replacement initially, with longhorn cattle (Rifkin, 1994: 74-6), and then with British cattle breeds (Velten, 2007: 149-50). Other species also needed to make way for the modern agricultural model and thus wolves and prairie dogs were exterminated as pests (Nibert, 2002: 45). The early meat factories of Chicago, established in 1865, have become the model for industrial slaughter in the developed world and increasingly, globally (Cronon, 1991).

The farming of animals is the prerequisite for this mass killing, and contains its own routines and practices of violence, as might be seen in the case of chicken-meat and egg production. From the 1950s through to the 1970s, one of the most important developments was the development of factory farming, which began with the confinement of chickens for both eggs and meat and was a means of significantly increased 'efficiency' and profit (Mason and Finelli, 2006). Advances in animal breeding technology has genetically increased the metabolism of chickens to ensure passivity and quick fattening (Marcus, 2005: 11). Kept in highly regulated conditions of heat and light in order to keep them 
calm, most chickens are reared in large numbers in windowless sheds until they are killed at between four and seven weeks (CIWF, 2009). 'Free range' describes a variety of arrangements where hens have access to outside runs and are afforded another one or two months of 'life'. Male birds in the egg industry are superfluous, and killed by gassing or mechanical mincing, or are discarded and left to die from smothering (FAWC, 2009).

Animals in less intensive systems still have radically foreshortened and difficult lives. For example, cattle in Britain are fattened quickly and slaughtered below eighteen months; dairy cattle are usually slaughtered by six or seven years of age when their productivity reduces. The calves they must produce will be kept or sold for dairy production, sold for veal or beef production, or often, shot (Stevenson, 1993). Most beef and dairy cattle are reared on a 'free range' system, but whatever the life 'quality' of a farmed animal might be, its relation with us is predicated on an early death usually via the slaughterhouse. Animals are transported (and often exported) to slaughter in conditions of extreme discomfort tightly packed, and subject to overheating, suffocation and crushing. There are, undoubtedly, examples of good practice, where people working with agricultural animals on a small scale, treat them with care and respect until the point of their greatly premature deaths (Wilkie, 2010: 89-114). Yet contemporary animal farming in a country such as the UK is overwhelmingly large scale and for some species (birds, pigs) operates predominantly on a warehouse model where disengagement rather than positive interaction with animals is a key feature of the organization of labour.

In industrialized modes of slaughter, technologies have maximized the speed and ease of killing. Gail Eisenitz's (1997) study of contemporary US slaughterhouses revealed alarming tales of systematic and normative cruelty against animals. In my own observations in the 1990s, I saw animals sworn at, 
and electric goads used to hurry them. These are perhaps better seen as incidental rather than endemic violences. Whilst there was a consensus amongst the inspectorate and abattoir management that killing had become more efficient and less traumatic for the animals killed with the introduction of stunning (interviews London and Essex, 1993-4), these increasingly detached forms of the dispatching of animals are prompted more by concern for speed and this profit, than for welfare (Burt, 2006). Cattle are stunned by a captive bolt pistol which administers a bullet which penetrates the brain and is usually effective with a single shot. Pigs, sheep and goats, are less effectively stunned by the use of electrical tongs that are regularly applied for a fewer seconds than required. Some sheep may be more successfully stunned by electrocution whilst less fortunate pigs may be gassed (Stephenson, 1993). According to both animal welfare groups and the Official Veterinary Service in the UK, many animals are immobilized but remain sensitive to pain and may recover full consciousness (FAWC, 2003). Pigs, for example, may reach the scalding tank conscious, and die from drowning (Gellatley, 1996: 102-104), despite having had an electric shock and their throat slit. Similarly, birds often rise in the shackles by which they are confined, 'flying' over the electrified water bath and reaching the automatic knife conscious (CIWF, 2001; FAWC, 2009). The killing of cattle, sheep, pigs and goats is via the slitting of the animals throat, followed by a process known as 'sticking' wherein a large knife is 'stuck' with some force down into the animal's chest cavity in order to ensure fast blood loss and full brain death (interview, local authority meat inspector, January 1994). According to those who teach the skill at Smithfield market, the largest meat market in London, it takes a 'certain kind of person' to slaughter, one who has 'disregard for the lives of animals' and has 'got to be callous' (interview, butcher and tutor, Smithfield Meat Market, November 1993). 
The institutions of animal agriculture from breeding, growing to killing are constituted through forms of violence that are regularised and for the most part, legitimate. Reproductive violence includes rape, in the form of forced intercourse between non-human animals (where farm workers for example, may force boars to mount sows, inserts their penises by hand) or by inserting human hands, arms, instruments of various kinds to artificially inseminate. There are also more ambiguous treatments which animals are subjected to, such as forced confinement and the inability to express species-life behaviours, which can be understood as forms of violence (WHO, 2002). Most extreme yet entirely normative, are the violences of slaughter involving gassing, shooting, electrocution and the slitting of the throats of tens of billions of animals a year.

The killing of food animals, certainly in most industrialised nations, is largely invisible in the public domain. Although the cultural visibility of animal killing is rare, it does not disturb the normative presumption that agricultural animals in particular, exist to be killed for food. The BBC3 television series 'Kill it, Cook it, Eat it' brought the rearing and killing of animals for food to a mainstream television audience. The first series in 2007 covered the rearing and killing of pigs, sheep, and cattle. The second, in 2008, covered 'baby animals' and the production of kid, veal, suckling pig and 'milk-fed lamb'. In 2009, the focus was on the hunting and killing of 'game'. The programmes represented the highest standards of animal welfare available in the farming and slaughter of animals, and this was reinforced for the audience and programme participants, alongside the message that the killing of animals is routine, unexceptional and part of the fabric of 'British life'.

\section{Thinking about species violence}


The domination of non-human animals in contemporary Western societies might be understood as constituted through groups of social relations which can be found in particular arenas. Animal agriculture and the pet industry are institutional systems and sets of production relations endemic to human domination. The lives, deaths and dismemberments of animals for 'meat' articulates a range of forms and degrees of physical and psychological harms, and such violence reflects the complex intersections of relations of social power. These social relations are framed by law, culturally mediated and politically supported. They are also contested through discourses of welfarism, rights and emancipation. Despite continued contestation however, the scale of this violence has undoubtedly increased both gradually with the development of the global system of animal farming since the eighteenth century, and quickly with the development of intensive agriculture since the 1950s. Whilst the killing of animals is nothing new, the scale and intensity is unprecedented.

Violence against animals, exemplified here by the killing of companion and food animals in the West, is institutionalised and constitutive of the social relations of species which privilege the human. This violence is state sanctioned in all countries in the world, although the species against which particular forms of violence can be carried out may differ. For example, many states in federal India ban cow slaughter, whilst the breeding, fattening of dogs for meat is legal and normative in parts of China. Violence against animals is also coconstitutive of forms of complex inequality, with the development of the contemporary global meat industry bound up with relations of capitalism, colonialism and patriarchy for example, or the systematic deployment of what is not simply 'intra-personal' violence against companion animals in a domestic context. The deployment of institutionalised violence is greater in industrial modernity and increases in level and tendency with these processes, 
at the same time, the practices of violence become increasingly regularised and extremes of violent practice may be de-legitimated, and some practices criminalised.

This paper has argued that violence towards domesticated animals is routinized, systemic and legitimated. It is embedded in structures of authority, such as the nation state, and in formations of social domination. In Britain, as elsewhere, domestic animals are legally constituted as property, and legislative moves to limit violent practices against animals deal with the extreme instances of 'cruelty' in individual or corporate cases, rather than the regularised legitimated violent practices embedded in everyday human interactions with non-human animals. Whilst the articulation of claims for rights and welfare improvements may have been effectual in the last seventy years in ameliorating some of the extremes of violent behaviour, it cannot challenge the social domination of non-human species. Indeed, the articulation of political claims on behalf 'of' animals has proceeded alongside the global spread of Western intensive animal agriculture and an enormous increase in animal populations bred and killed for food. Where the lives of domesticated non-human animals are concerned Bauman's (1989) thesis is vindicated - modernity has organised violence with ever greater efficiency.

In the light of the scale and intensity of violence affecting non-human animals, and the ways this is constituted through social institutions, practices and relationships, the agendas of the emerging sociology of violence need to take account of the more-than-human world. The mass killing of a small number of animal species, whether for food, or whether as unwanted companions demonstrates the ways in which violence constitutes a distinctive practice clearly linked to sets of social relations in which human interests are prioritised. Within the practices associated with the harm to, and the killing of, 
domesticate animals, violence can be understood as operating on a variety of levels (from violence against pets in the home, to the meso scale of the slaughter businesses and the networks of global breeding exchanges and transportation). Species violence is apparent in domestic contexts, local institutions and reflected in national political priorities and interstate agreement, it is embedded in everyday practices, institutionalised across various scales - local, national and transnational. A humancentrist agenda for the sociology of violence excludes the ways non-human beings are caught up in violent social practices which are wide scale, systemic and normalized. Given the development of sociological animal studies and the ways it has troubled the human-exclusive, partial agendas of the discipline as it has emerged historically (Peggs, 2012), new developments might show caution and at the very least be open to inclusion.

\section{$\underline{\text { References }}$}

Adams, C. J., (1995), 'Woman Battering and Harm to Animals', in C. J. Adams and J. Donnovan (eds), Animals and Women: Feminist Theoretical Explorations, Durham, N. Carolina: Duke University Press. Alger, J. M., (2003), 'Drawing the line', International Journal of Sociology and Social Policy, 23(3): 69-93.

The Animal Studies Group, (2006), Killing Animals, Urbana and Chicago: University of Illinois Press.

Arendt, H., (1970), On Violence, Orlando, Fl.: Harcourt.

Arluke, A., (2004), A Sociology of Sociological Animal Studies, Society and Animals, 10(4): 369-374.

Ascione, F., (1997), 'The Abuse of Animals and Domestic Violence: A National Survey of Shelters for Women who are Battered', Society and 
Animals, 5: 205-218.

Barkham, P. and Murphy, S., (2012), 'Bark but No Bite: Dangerous Dogs Act in Spotlight as Attacks Rise' The Guardian, 18 $8^{\text {th }}$ January, 2012 available at: http://www.guardian.co.uk/uk/2012/jan/18/dangerous-dogs-act-inspotlight.

Bauman, Z., (1989), Modernity and the Holocaust, Cambridge: Polity.

Bekoff, M., (2002), Minding animals: Awareness, Emotion and Heart. New York: Oxford University Press.

Bock, B., and Buller, H. J., (2013). 'Healthy, Happy and Humane: Evidence in Farm Animal Welfare Policy'. Sociologia Ruralis, 53(3): 390-411.

Burt, J. (2006), 'Conflicts Around slaughter in Modernity', in The Animal Studies Group, Killing Animals, Urbana and Chicago: University of Illinois Press.

Cockburn, C., (2007), From Where We Stand: War, Women's Activism and Feminist Analysis, London: Zed.

Cohn, C., (ed.) Women and Wars, Cambridge: Polity.

Compassion in World Farming (CIWF), (2009), Factsheet: Pigs, September 2009, Compassion in World Farming, available from www.ciwf.org.uk. Compassion in World Farming (CIWF), (2001), Animal Welfare Problems in UK Slaughterhouses, Compassion in World Farming, available from www.ciwf.org.uk.

Compassion in World Farming (CIWF), (2009), Factsheet: Meat Chicken, March 2010, Compassion in World Farming, available from www.ciwf.org.uk. Cronon, W., (1991), Natures Metropolis: Chicago and the Great West, London: Norton.

Author, (2008), Author, (2011a), 
Author, (2011b),

Author and author, (2014)

Dangerous Dogs Act (1991) retrieved from:

http://www.legislation.gov.uk/ukpga/1991/65/contents

Department for Environment, Food and Rural Affairs (Defra), (2009),

Dangerous Dogs Law: Guidance for Enforcers, London: Department for Environment, Food and Rural Affairs.

Derrida, J., (1991) “'Eating Well,' or the Calculation of the Subject: An Interview with Jacques Derrida." In E. Cadaver, P. Connor and J-L. Nancy (eds), Who Comes After the Subject, London: Routledge. 96-119.

Derrida, J., (2009) The Beast and the Sovereign Volume 1, M. Lisse, M-L.

Mallet and G. Michaud (eds.), G. Bennington (trans.), Chicago and London: Chicago University Press.

Eisenitz, G., (1997), Slaughterhouse: The Shocking Tales of Greed, Neglect and Inhumane Treatment inside the U.S. Meat Industry, New York: Prometheus Books.

Enloe, C., (2000), Maneuvers: The International Politics of Militarizing Women's Lives, Berkeley: University of California Press.

Enloe, C., (2007), Globalization and Militarism: Feminists Make the Link, New York: Rowman and Littlefield.

Farm Animal Welfare Council, FAWC, (2003), Welfare of Farmed Animals at Slaughter or Killing: Part 1 Red Meat Animals, June 2003, London: Farm Animal Welfare Council.

Farm Animal Welfare Council, FAWC, (2009), Welfare of Farmed Animals at Slaughter or Killing: Part 2 White Meat Animals, May 2009, London: Farm Animal Welfare Council.

Flynn, C. P., (2000), ‘Battered Women and Their Animal Companions: 
Symbolic Interaction Between Human and Non-Human Animals', Society and Animals, 8: 99-127.

Food and Agriculture Organization of the United Nations, (2002), World Agriculture: Towards 2015/2030: Summary report, retrieved from ftp://ftp.fao.org/docrep/fao/004/y3557e/y3557e.pdf.

Francione, G. (2008) Animals as Persons: Essays on the Abolition of animal Expolitation, New York: Columbia University Press.

Gellatley, J., (1994), The Silent Ark: A Chilling Expose of Meat - the Global Killer, London: Thorsons.

Giddens, A., (1985), The Nation State and Violence (Volume 2), Cambridge: Polity. Grandin, T. and Johnson, C., (2009), Animals Make Us human: Creating the Best Life for Animals, Orlando: Houghton Miflin Harcourt.

Hediger, R., (ed.), Animals and War: Studies of Europe and North America, Lievan: Brill.

Leatherman, J. L., (2011), Sexual Violence and Armed Conflict, Cambridge: Polity. Le Duff, C., (1999), 'At the Slaughterhouse, Some Things Never Die', reprinted in C. Wolfe, (ed.), (2003), Zoontologies: The Question of the Animal, Minneapolis: University of Minnesota Press.

McHugh, S., (2004), Dog, London: Reaktion Books.

McKie, L., (2006) 'Sociological Work on Violence: Gender, Theory and Research', Sociological Research Online, 11, 2.

Marvin, G., (2006), 'Wild Killing: Contesting the Animal in Hunting', in The Animal Studies Group, Killing Animals, Urbana and Chicago: University of Illinois Press.

Mason, J. and Finelli, M., (2006), 'Brave New Farm?', in P. Singer (ed.), In Defense of Animals: The Second Wave Oxford: Blackwell.

Miele, M. and Lever, J., (2013), 'Civilizing the market for welfare friendly 
products in Europe? The techno-ethics of the Welfare Quality assessment.' Geoforum 48: 63-72.

Miele, M., (2013), 'Religious slaughter: Promoting a dialogue about the welfare of animals at time of killing', Society and Animals 21(5), pp. 421-424.

Mitchell, L., (2011), ‘Moral Disengagement and Support for Nonhuman Animal Farming', Society $\mathcal{E}$ Animals, 19: 38-58.

Nibert, D., (2002), Animal Rights/Human Rights: Entanglements of Oppression and Liberation, Lanham, Maryland: Rowman and Littlefield.

Nibert, D., (2013), Animal Oppression and Human Violence: Domesecration, Capitalism and Global Conflict, New York: Colombia University Press.

Palmer, C., (2006), 'Killing Animals in Animal Shelters', in Killing Animals, The Animal Studies Group, (ed.), Urbana and Chicago: University of Illinois Press: 170-187.

Pateman, C., (1988), The Sexual Contract, Cambridge: Polity.

Pierce, J., (2012) The Last Walk: Reflections on Our Pets at the End of Their Lives. Chicago and London: Chicago University Press.

Peggs, K., (2012), Animals and Sociology, Basingstoke: Palgrave.

Plumwood, V., (1996), 'Being Prey,' from Travellers' Tales: the Ultimate Journey, val.plumwood.files@wordpress.com.

Ray, L., (2000), 'Memory, Violence and Identity', in J. Eldridge, J. MacInnes, S. Scott, C. Warhurst and A. Witz, (eds.), For Sociology: Legacies and Prospects, York: Sociology Press: 145-159.

Ray, L., (2011), Violence and Society, London: Sage.

Rifkin, J., (1994), Beyond Beef: the Rise and Fall of Cattle Culture, London: Thorsons.

RSPCA, (2014) ‘Breed Specific Legislation: Don't believe the type!' retrieved at http://www.rspca.org.uk/getinvolved/campaigns/dogownership/bsl 
(accessed 15.2.2014).

Scott, J., (2010), 'Sociology and the sociological imagination: reflections on interdisciplinarity and intellectual specialisation', in J. Burnett, S. Jeffers and G. Thomas, (eds), New Social Connections: Sociology's Subjects and Objects, Basingstoke: Palgrave.

Stanko, E., (2001), 'The Day to Count: Reflections on a Methodology to Raise Awareness about the Impact of Domestic Violence in the UK', Criminology and Criminal Justice, 1: 215-226.

Stevenson, P., (1993), Report: The Welfare of Pigs, Cattle and Sheep at Slaughter, Compassion in World Farming, available from www.ciwf.org.uk.

Swabe, J. (2009) 'Veterinary Dilemmas', in A. Arluke and C. Saunders (eds.) Between the Species: Readings in Human-Animal Relations. New York: Pearson.

Tester, K., (1991), Animals and Society: The Humanity of Animal Rights, London: Routledge.

Tickner, J. A., (2001), Gendering World Politics: Issues and Approaches in the PostCold War Era, New York: Columbia University Press.

Tilly, C. (2003), The Politics of Collective Violence, Cambridge: Cambridge University Press.

Torres, B., (2007), Making a Killing: The Political Economy of Animal Rights, Oakland, CA: AK Press.

Velten, H., (2007), Cow. London: Reaktion Books.

Walby, S., (2009), Globalisation and Inequalities: Complexity and Contested Modernities, London: Sage.

Walby, S., (2013), ‘Violence and Society: an Introduction to an Emerging Field of Sociology', Current Sociology, 61(2): 95-111.

Weber, M., (1978) Economy and Society: an Outline of an Interpretive Sociology, 
Volume 1, Berkeley, Ca.: University of California Press.

Wedderburn, P. (2010) 'Dangerous Dogs: Time for a New Approach', Daily

Telegraph, $5^{\text {th }}$ July, 2010, available at:

Http://blogs.telegraph.co.uk/news/peterwedderburn.

Wilkie, R. (2010) Livestock/Deadstock: Working with Farm Animals from Birth to Slaughter. Philadelphia: Temple University Press.

Williams, E. E. and De Mello M., (2007), Why Animals Matter: the Case for Animal Protection, Amherst: Prometheus Books.

Wolfe, C., (2013), Before the Law: Human and Other Animals in Biopolitical Frame. Chicago and London: Chicago University Press.

World Health Organization, (2002), World Report on Violence and Health, Geneva: WHO. 